Motrivivência $\quad$ Ano XXIII, No 36, P. 07-25 Jun./2011

doi: 10.5007/2175-8042.2011v23n36p07

\title{
O MUNDO DO TRABALHO, OS MEGAEVENTOS ESPORTIVOS E A CRISE ESTRUTURAL DO CAPITAL
}

Tá vendo aquele edifício, moço Ajudei a levantar

Foi um tempo de aflição

Eram quatro condução

Duas prá ir, duas prá voltar

Hoje depois dele pronto

Olho prá cima e fico tonto

Mas me vem um cidadão

E me diz desconfiado

"Tu tá aí admirado?

Ou tá querendo roubar?"

Meu domingo tá perdido

Vou prá casa entristecido

Dá vontade de beber

E prá aumentar meu tédio

Eu nem posso olhar pro prédio

Que eu ajudei a fazer...

Tá vendo aquele colégio, moço

Eu também trabalhei lá

Lá eu quase me arrebento

Fiz a massa, pus cimento

Ajudei a rebocar

Minha filha inocente

Vem prá mim toda contente

"Pai vou me matricular"

Mas me diz um cidadão:

"Criança de pé no chão

Aqui não pode estudar"

(Trecho da Música

Cidadão de Zé Geraldo)

Iniciamos este editorial com uma homenagem póstuma ao cidadão-trabalhador Joelson de Moura, que no dia 03 de maio de
2011 perdeu a vida num acidente durante a construção do novo prédio do Centro de Desportos da UFSC. Foi então que o operário 
em construção ${ }^{1}$... Tropeçou no céu como se fosse um bêbado; E flutuou no ar como se fosse um pássaro; $E$ se acabou no chão feito um pacote flácido; Agonizou no meio do passeio público; Morreu na contramão atrapalhando o tráfego ${ }^{2}$.

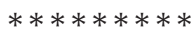

Esta edição tem como objetivo continuar as reflexões iniciadas na edição passada, à medida que os textos trazem mais elementos para pensar criticamente o mundo do trabalho e suas relações com as questões objetivas da Educação Física, Esportes e Lazer. Como havíamos afirmado naquele número, a opção em publicar dois exemplares sobre esta temática se deu, em primeiro lugar, pela relevância da problemática para aqueles que lidam com as práticas corporais, tanto nos âmbitos públicos quanto privados, em espaços educativos formais (escolas) e não-formais (academias, clubes, escolhinhas esportivas e outras). Em segundo lugar, pela enorme demanda de textos oriundos de teses de doutorado, dissertações de mestrado e outros artigos inéditos. Esse fato traduz a emergência da problemática em apreço, em razão da agudez da crise estrutural do capital e seus desdobramentos nas diversas instâncias da vida social e idiossincrasias do corpo produtivo nos diversos mundos do trabalho (exploração, trabalho escravo, trabalho precário entre outros). Todo esse quadro reverbera na Educação Física, na qual há evidências teóricas e empíricas que apontam para o desemprego e a precarização flexível. Isso se dá pela exploração da força humana de trabalho dos professores de Educação Física que atuam em instâncias privadas (academias, clubes, hotéis e outras); além da precarização do trabalho (subemprego) dos contratos temporários do professor ACT (admitido em caráter temporário) nas Secretarias de Educação, conforme anunciamos da edição passada.

Acreditamos que uma produção tão expressiva no âmbito das tensões entre capital e trabalho na Educação Física se dá, sobretudo, em razão das determinações engendradas no mundo do trabalho no Brasil e no mundo; notadamente, no que diz respeito à exploração, desemprego e subemprego. No Brasil, numa incursão de caráter mais genérico no mundo do trabaIho, pode-se evocar alguns focos de exploração da força humana de trabalho (precarização) nos

1 O Operário em Construção, poema de Vinicius de Moraes.

2 Construção, Chico Buarque de Hollanda. 
âmbitos rural e urbano, tais como na construção civil, a terceirização na indústria automotiva e metalúrgica, bancos, mundo virtual das telecomunicações, feminilização do telemarketing ${ }^{3}$, trabalho imaterial dos cantores de espetáculos líricos, do assalariamento e relações de gênero nas orquestras, produção e desregulamentação na indústria têxtil e de confecção na indústria de calçados entre outros ${ }^{4}$. De todo esse processo de reprodução do capital, emergem, ainda, temas tais como trabalho e gênero e outros ${ }^{5}$, trabalho e migração internacional (bolivianos e paraguaios em São Paulo), trabaIho dos caminhoneiros, trabalho e pobreza, trabalho e envelhecimento, trabalho e sofrimento e saúde do trabalhador, saúde dos professores (o mal estar docente) ${ }^{6}$, síndrome de Burnout, trabalho e violência (assédio moral $)^{7}$, acidentes de trabalho, o trabalho intensificado nas universidades federais:pós-graduação e produtivismo acadêmico ${ }^{8}$.

Quanto aos acidentes de trabalho, são inúmeras as situações e episódios que vem pondo em risco a saúde do trabalhador, como por exemplo, o sofrimento dos trabalhadores na Agroindústria de Chapecó/SC $C^{9}$. Trata-se da violência no trabalho, que verifica sob corpos produtivos dos trabaIhadores dos frigoríficos da cidade de Chapecó e entorno, reduzidos apenas à Carne e Osso ${ }^{10}$. Esse tipo de atividade laboral se caracteriza pela periculosidade e insalubridade dos acidentes de trabalho, devido à intensa exploração das capacidades humanas, em prol de uma acumulação de riqueza despótica e cada vez mais desterritorializada.

3 ANTUNES,Ricardo. Riqueza e Miséria do Trabalho no Brasil. São Paulo: Boitempo, 2006.

4 ANTUNES, Ricardo; SILVA, Maria A. M. (orgs.). O avesso do trabalho. São Paulo: Expressão Popular, 2010.

5 SANT`ANA, Raquel (org.). O avesso do trabalho II. São Paulo: Expressão Popular, 2010.

6 ZARAGOZA, José Manuel Esteve. O Mal-Estar Docente: a sala de aula e a saúde dos professores. Bauru/SP: EDUSC, 1999.

7 CODO, Wanderley (org.). Educação, Carinho e Trabalho: Burnot, a síndrome da desistência do educador, que pode levar à falência da Educação. Brasília: UNB. Laboratório de Psicologia do Trabalho, 2006.

Ver também: MENDES, Ana M. Violência no trabalho: perspectivas da psicodinâmica, da ergonomia e da sociologia clínica. São Paulo: Universidade Presbiteriana Mackenzie, 2010.

8 SGUISSARDI, Valdemar; SILVA JÚNOR, João dos R. O trabalho intensificado nas federais: Pósgraduação e Produtivismo Acadêmico. São Paulo: Xamã, 2009.

9 SANTOS, Maria Aparecida. O sofrimento dos Trabalhadores da Agroindústria Sadia S/A de Chapecó. Dissertação (Mestrado em Serviço Social). Florianópolis: UFSC, 2011. 
Trata-se, segundo dados da OIT, de 270 milhões de trabalhadores assalariados em todo o mundo vítimas de acidentes de trabalho que levam ao adoecimento (afecções músculoesqueléticas, estresse, LER/DORT, problemas psíquicos, reações asmáticas e alérgicas, doenças decorrentes da exposição a agentes tóxicos). Estima-se que aproximadamente 2,2 milhões deles resultem em óbitos. No Brasil, segundo o relatório, são 1,3 milhão de casos, que têm como principais causas o descumprimento de normas básicas de proteção aos trabalhadores e más condições nos ambientes e processos de trabalho ${ }^{11}$. Esse fenômeno, inerente à exploração capitalista, tem afastado inúmeros trabalhadores por jornadas de trabalho intensas, penosas e repetitivas. Em síntese, o que está em pauta na ordem do capital é a destruição das forças produtivas, isto é, dos direitos dos trabalhadores no Brasil em todo o planeta. Esta se materializa no mundo laboral cotidiano como o trabalho sem carteira assinada, também chamado pela juventude espanhola de contratobasura (contrato lixo).

Quando se analisa o mundo do trabalho sob o ponto de vista de classe e geração, percebe-se pelas estatísticas e dados qualitativos uma tendência ao aumento das taxas de desemprego e da precarização da força humana de trabalho. No que se refere à exploração do trabalho infantil, crescem as taxas de inserção das crianças no trabalho precoce nos diversos continentes como a América Latina, África e Ásia. Neste último, as crianças produzem bolas para a Nike, que terceiriza toda a produção $^{12}$. No Brasil, há, de um lado, o mito da erradicação ou diminuição dos dados estatísticos oficiais que são manipulados para efeitos político-eleitoreiros, levando em conta apenas os dados quantitativos, sem nenhum questionamento sobre as dimensões qualitativas das cifras. De outro lado, percebe-se que os discursos ideológicos sobre o fetiche da diminuição ou da suposta erradicação da exploração do trabalho infantil nestes meandros, está diretamente atrelada à propaganda ideológica da inclusão social, impactada pelo advento da Bolsa Família. Neste sentido, há necessidade do envolvimento mais efetivo dos movimentos sociais e sindicatos, no sentido de aprofundar estas críticas e levantar novas frentes de luta contra o uso político-ideológico dos dados estatísticos oficiais sobre

11 PINTO, Geraldo Augusto. A organização do trabalho no século 20. São Paulo: Expressão Popular, 2007.

12 CHIAVENATO, Júlio José. Ética Globalizada e Sociedade de Consumo. São Paulo: Moderna, 2004. 
a exploração do trabalho infantil, considerando que o desemprego dos adultos (pais) provoca a inserção de um grande contingente de crianças, precocemente, no mundo do trabalho. É importante destacar que essa distorção e manipulação dos dados sobre a pobreza mundial da classe trabalhadora e, consecutivamente, da exploração do trabalho infantil, tem como o fim único a perpetuação do modo de produção capitalista. A perpetuação do capital está assentada no desenvolvimento histórico deste próprio modo de produção, cujo objetivo é a autovalorização do capital ${ }^{13}$.

No que se refere à juventude, as estatísticas apontam para a ineficiência das políticas públicas para o chamado "primeiro emprego". Isto faz com que a trajetória dos jovens e sua inserção no "mercado de trabalho" seja, de modo contundente, marcada pelo desemprego e precarização. Os dados estatísticos evidenciam que as taxas de desemprego e precarização da ocupação profissional vem subindo vertiginosamente nos últimos anos. De acordo com o DIEESE, existem 3,7 milhões de jovens desempregados, representando $45 \%$ do total dos desempregados no país ${ }^{14}$. Em linhas gerais, pode-se dizer que o desemprego e a precarização do trabalho dos adultos é uma fatalidade transgeracional, que está intimamente relacionada com alto grau de exploração que começa na infância, passando pela juventude e culminando com o processo aviltante e alienante da condição humana na aposentadoria.

Esse quadro se situa na perspectiva da crise da sociedade capitalista que, de uma maneira geral, pode ser concebida como o colapso dos princípios básicos de funcionamento da sociedade. Colapso que é gerado pelo processo de acumulação, determinado pela tendência crescente da taxa de juros. No entanto, há uma diferença entre as crises e colapsos parciais e as crises que conduzem à transformação de uma sociedade ou formação social. As crises ou colapsos sociais dizem respeito a fenômenos como os ciclos econômicos que abrangem surtos de prosperidade aparentemente intermináveis e seguidos de graves declínios da atividade econômica, constituindo-se numa face crônica do capitalismo. As crises que conduzem à transformação da

13 SILVA, Maurício Roberto. Afinal, Acabou a Exploração do Trabalho Infantil na Zona da Mata canavieira de Pernambuco? Anais do XXVIII Congresso Internacional da Associação LatinoAmericana de Sociologia. Recife: setembro de 2011.

14 SILVA, José Humberto. Os filhos itinerantes do primeiro emprego. Brasília: Liber Livro, 2009. 
sociedade ou formação social são a tradução do enfraquecimento do princípio organizador ou nuclear de uma sociedade, quer dizer, a erosão ou destruição daquelas relações societais que determinam o alcance e os limites da transformação da atividade política,econômica e outras. Em síntese, pode-se abstrair que a crise é constitutiva do modo de produção capitalista, não existindo, portanto, capitalismo sem crise; as crises sempre existirão, principalmente, pelo fato da sociedade capitalista ser marcada pela contradição antagônica entre as classes sociais (proletariado e burguesia) ${ }^{15}$.

A crise do capitalismo atual é chamada de crise estrutural do capital'16. Mészáros, através de densa investigação, faz uma profunda e devastadora crítica às engrenagens que caracterizam o sistema sociometabólico do capital, debruçando-se ao longo de todo o século XX. O autor constata que o sistema do capital não tem limites para a sua expansão, convertendose numa processualidade incontrolável e profundamente destrutiva. Tudo isso se passa a partir do que Marx chamou de mediações de segunda ordem, isto é, quando tudo passa a ser controlado pela lógica de valorização do capital, que não leva em consideração os imperativos humano-societais vitais. A produção e o consumo supérfluos acabam por gerar a corrosão do trabalho, que tem como conseqüência a precarização e o desemprego estrutural, além de impulsionar uma destruição da natureza em escala planetária jamais observada anteriormente. Essa expansão destrutiva do sistema do capital se dá na busca crescente e desmedida de mais-valor, pautando-se pela superfluidade e descartabilidade sem limites. Todo esse processo, baseado num longo período dominado pelos ciclos, faz com que o sistema venha assumindo, de acordo a formulação de Mészáros, a forma de uma crise endêmica, cumulativa, crônica e permanente. Esse fato faz com que, devido ao espectro de destruição global, busquemos uma alternativa societa visando à construção de um novo modo de produção e de um novo modo de vida, cabal e frontalmente contrário à lógica destrutiva do capital hoje dominante ${ }^{17}$.

A crise de dominação do capital se alastra com seus problemas e acirrando contradições cada

15 HARVEY, David. The Enigma of Capital. Oxford: University Press, 2011.

16 MÉSZÁROS, Istvan. A Crise Estrutural do Capital. São Paulo: Boitempo, 2011.

17 ANTUNES, Ricardo. Introdução: Substância da Crise. In: MÉSZÁROS, Istvan. A Crise Estrutural do Capital. São Paulo: Boitempo, 2011. 
vez mais explosivas. Neste sentido, há uma tendência objetiva inerente à natureza do capital e seu crescimento dentro de um sistema global conjugado com sua contração e sua sempre articulação com a ciência e tecnologia, cujos efeitos abalam e tornam anacrônica a subordinação socioestrutural do trabalho ao capital. Todavia, num mundo constituído por uma multiplicidade de sistemas sociais conflitantes e em mútua interação em contraste com o mundo fantasioso das escaladas e desescaladas do tabuleiro de xadrez, o precário status quo global caminha certamente para uma ruptura. Neste sentido, ficam as seguintes reflexões: a questão não é se haverá ruptura ou não, mas sim, por que meios vão ocorrer ${ }^{18}$.

O capital se organiza através do trabalho humano, seja de adultos ou de crianças e jovens, com fim de extração de mais-valia. Todo esse processo se verifica em diferentes crises cíclicas do capital, ocorridas em distintos períodos da história. A atual crise estrutural do capital, como já foi mencionado, é uma crise longeva, duradoura, sistêmica e estrutural, que, a partir de suas contradições antagônicas de classe entre proletariado e burguesia (desigualdades sociais) e capital e trabalho (desemprego, subemprego), está destinada piorar consideravelmente no estágio atual de desenvolvimento. Ela pode vir a se tornar mais aguda no sentido de invadir não apenas o mundo das finanças globais, mais ou menos parasitárias, mas também todos os domínios da nossa vida econômica, social e cultural ${ }^{19}$.

Urge perguntar: se o capital se romperá por meios militares e de guerras devastadores como já vem ocorrendo ou haverá válvulas sociais adequadas para o alívio das crescentes tensões sociais, que hoje estão em evidência mesmo nos cantos mais remotos do nosso espaço social global? Esse movimento contra-ideológico e revolucionário só será possível a partir do sucesso ou criação dos necessários movimentos estratégicos e instrumentos capazes de assegurar uma efetiva transição para uma sociedade, socialista, na qual a humanidade possa encontrar a unidade que necessita para a sua simples sobrevivência ${ }^{20}$. Em suma: é necessário que no decurso do desenvolvimento humano, a função do controle social não seja desalienada do corpo social e transferida para o capital. Este não pode ter o poder de

18 MÉSZÁROS, Istvan. A Crise Estrutural do Capital. São Paulo: Boitempo, 2011.

19 Ibid.

20 Ibid. 
aglutinar os indivíduos num padrão hierárquico estrutural e funcional, de acordo com o critério de maior ou menor participação no controle da produção e da distribuição.

Vale ressaltar que a crise estrutural do capital tem sido enfrentada e contestada pelos movimentos sociais em diversas partes do planeta, como, por exemplo, na Europa (Espanha, Grécia e outros) e, em especial, no mundo árabe como a chamada primavera árabe. Além desses movimentos, pode ser mencionada, nos Estados Unidos, a ocupação por miIhares de pessoas, acampadas numa praça próxima a Wall Street (Ocupe Wall Steet), do coração financeiro do mundo capitalista, em Nova York, desde 17 de setembro. Os protestos, liderados, predominantemente, por jovens e apoiado por intelectuais e artistas de esquerda, como Noam Chomsky, Michael Moore e outros, são contra o $1 \%$ de ricaços dos EUA que exploram 99\% da sociedade e que são culpados pela grave crise econômica que abala o país desde 2008, gerando desemprego, despejos e miséria. O significado da ocupação pode ser traduzido nas palavras de Noam Chomsky:

Wall Street e as instituições financeiras iniciaram o ciclo vicioso que levou a imensa concentração de riqueza e, com ela, também do poder político, em um pequeníssimo setor da população, uma fração de $1 \%$. Ao mesmo tempo, o restante da população foi transformado no que às vezes é chamado de 'precarizado' - lutando para sobreviver numa existência precária. Wall Street e as instituições financeiras também praticam com impunidade quase completa suas atividades nefastas: não só são 'grandes demais para quebrar'; também são 'grandes demais para ir pra cadeia'. Os corajosos e honrados protestos em curso em Wall Street devem chamar a atenção pública para essa calamidade".$^{21}$

É preciso mudar a tendência objetiva inerente ao desenvolvimento do capital em todas as esferas, buscando outros resultados diametralmente opostos ao interesse do capital, uma vez que o que está em jogo é a fragmentação mecânica do processo de trabalho e a criação de sistemas automatizados; a acumulação local de capital e sua concentração na forma de um sistema mundial em contínua expansão; a divisão parcial e local do trabalho e a vasta divisão internacional do

21 BORGES, Altamiro. Mídia esconde protestos em Wall Street. Disponível em: http//:www.iela. ufsc.br.04/10/2011 
trabalho; o consumo limitado ao consumo de massa artificialmente estimulado e manipulado a serviço de um ciclo de reprodução cada vez mais acelerado da sociedade de mercado; o tempo livre restrito a poucos privilegiados à produção em massa de uma bomba social, na forma de lazer, em escala universal ${ }^{22}$. Esse suposto tempo livre representa a síntese de múltiplos tempos sociais que, de forma complexa une o trabalho e a vida fora do trabalho, tornando-os, dialeticamente, partes constitutivas e intrinsecamente alienadas $^{23}$. É nesse tempo livre no qual o homem se integra voluntariamente a um tempo que não é mais o da existência, de seus prazeres, de seus desejos e de seu corpo, mas a um tempo que é o da continuidade da produção, do lucro ${ }^{24}$.

Como já mencionamos antes, a expansão destrutiva do sistema do capital se dá na busca crescente e desmedida de mais-valor, pautando-se pela superfluidade e descartabilidade dos trabalhadores em políticas de precária e marginal, sem limites, conforme as palavras de Viviane Forrester:

(...) Ao ver como se pregam e se jogam homens e mulheres em virtude de um mercado de trabalho errático, cada vez mais imaginário, comparável àquela "pele de onagro" que se encoIhe, um mercado do qual eles dependem, do qual suas vidas dependem, mas que não depende deles; ao ver como já não são contratados (sem grifos no original) com tanta freqüência, e como vegetam em particular os jovens (sem grifos no original), numa vacuidade sem limites, considerada degradante, e como são detestados por isso; ao ver como, a partir daí, a vida os maltrata e como a ajudamos a maltratá-los; ao ver que, para além da exploração dos homens, havia algo ainda pior: a ausência de qualquer exploração - como deixar de dizer que, não sendo sequer exploráveis (sem grifos no original), nem sequer necessárias à exploração, ela própria inútil, as multidões podem tremer, e cada um dentro da multidão? $\{\ldots\}$ Então como um eco aquela pergunta: "Será útil viver quando não se é lucrativo ao lucro?", ela própria eco daquela outra: "É preciso merecer viver para ter esse direito? Surge o temor insidioso, o medo difuso, mas

22 MÉSZÁROS, Istvan. A Crise Estrutural do Capital. São Paulo: Boitempo, 2011.

23 CARDOSO, Ana Cláudia M. Tempos de Trabalho, Tempos de Não Trabalho. São Paulo: Anna Blume, 2009.

24 NOVAES, Adauto. Elogio à Preguiça. Le Monde Diplomatique, agosto/2011. 
justificado, de ver um grande número de seres humanos considerados supérfluos (sem grifos no original). Não subalternos nem reprovados: supérfluos. e por essa razão, nocivos (sem grifos no original). E por essa razão... [...] incluídos até a medula... (sem grifos no original) ${ }^{25}$.

Essa faceta do horror econômico, descrito por Forrester, sinaliza a falência do capital, principalmente, se considerarmos as políticas públicas de trabalho, moradia, transporte, saúde, lazer e outras, que se constitui no drama cotidiano dos trabalhadores subempregados e desempregados ao percorrerem uma verdadeira via crucis aos centros de atendimento ao trabalhador. Eles são aqueles pobres, negros e mestiços, tidos como socialmente incapazes, cujo trabalho o capital desvalorizou e marginalizou. São aqueles:

Que freqüentam a escola, mas não se sentem acolhidos por ela e não aprendem o que cabe a ela ensinar; dos que moram, que sub-moram e dos que não moram; que produzem cultura e que consomem os consolos ideológicos fornecidos pela indústria cultural; $\{\ldots\}$ são aqueles que crescem em bairros que, destituídos de qualquer garantia de direitos sociais e civis, são governados pela violência do aparato repressivo, pelo tráfico de drogas como alternativa ao consumo e falta de perspectivas de trabalho e pela lógica perversa que estrutura estes dois mundos em estreita relação (sem grifos no original); dos que adoecem física e psiquicamente e são destratados onde deveriam ser cuidados (sem grifos no original) ${ }^{26}$.

$$
\begin{array}{r}
* * * * * * \\
\text { Conflitos entre trabalho e capital: do } \\
\text { "jogo sujo" na "construção" dos } \\
\text { megaeventos esportivos ao "jogo } \\
\text { limpo" da resistência } \\
\text { dos trabalhadores }
\end{array}
$$

A epígrafe da música mencionada na abertura deste editorial tem como intento refletir sobre as tensões, contradições e conflitos entre trabalho e capital, no limiar dos diversos mundos do trabalho e, em especial, na Educação Física, Esportes e Lazer. Ao elegermos os versos do poeta, pensamos, fundamentalmente, nos trabalhadores da construção civil, no âmbito da realização dos próximos megaeventos

25 FORRESTER, Viviane. O Horror Econômico. São Paulo: UNESP, 1997 (p.15-16).

26 PATO SOUZA, Maria Helena. A Cidadania Negada: Políticas Públicas e Formas de Viver. São Paulo: Casa do Psicólogo, 2009. 
no Brasil (Copa do Mundo de 2014 e os Jogos Olímpicos de 2016). Eles estão construindo estádios, prédios, ginásios de esportes, piscinas e outros espaços e equipamentos para a celebração da cultura esportiva e a unidade entre os povos, mas, provavelmente, não terão acesso a esses bens materiais construídos por eles próprios.

O cimento e os andaimes que dão solidez às construções ludo-esportivas estão assentados nos edifícios e equipamentos urbanos da cidade do capital ou city marketing. A city marketing é a cidademodelo, é a cidade-mercadoria, a ser comprada e vendida à revelia das demandas da classe trabalhadora empobrecida, acentuando assim a divisão espacial e de classe, no solo da urbe. A city se opõe à polis, o mercado subordina, quando não elimina, a ágora. Assim, a cidade se converte no palco e no estádio das mercadorias esportivo-culturais, abrindo-se o leque de possibilidades mercantis sob as determinações das agendas e negócios do esporte e da mídia ${ }^{27}$. Na ideologia da city marketing, os planos estratégicos de cidade aparecem como importantes instrumentos do chamado novo planejamento estratégico, que visa recuperar sua legitimidade quanto à intervenção pública na perspectiva de colocar as cidades no novo mapa do mundo pela via da indústria do turismo. Na perspectiva da cidade do marketing, a produção de imagens cumpre um papel cada vez mais relevante no que diz respeito à formulação de novas estratégias econômicas e urbanas, orientadas, principalmente, para a internacionalização da cidade, mas também para a obtenção de notáveis efeitos internos, particularmente no que se refere à construção de uma ampla adesão social a um determinado modelo de gestão e administração da cidade. Em síntese, isto significa dizer que as políticas de reestruturação espacial, na inter-relação com os projetos de reestruturação econômica mundial, apresentam uma ordem complexa e mutante que permeia todas as escalas do espaço, em especial as cidades ${ }^{28}$.

A cidade-mercadoria é construída sob a égide da divisão social espacial, isto é, da divisão de classes sociais, cujo processo e repercussão concreta se dá na perspectiva da reprodução e perpetuação do capitalismo. A cidade

27 PIRES, Giovani De Lorenzi (org.). O Brasil na Copa: a Copa no Brasil. Florianópolis: Tribo da Ilha, 2011.

28 SANCHEZ, Fernanda. A Reinvenção das Cidades: para um mercado mundial. Chapecó, SC: Argos, 2010 (p.15-20). 
do capital opera na dimensão da propriedade do solo e da renda fundiária no quadro urbano, focalizando a formação, realização e distribuição da mais-valia. As cidades são projetadas normalmente para a circulação de bens materiais, bens, serviços e mercadorias, cuja finalidade é atender apenas às demandas do capital e não aos interesses dos trabalhadores que efetivamente constroem as cidades com a força de trabalho humano. Em síntese, as cidades são projetadas para servir aos interesses burgueses, aos donos do capital. A mobilidade social de crianças, jovens, adultos, velhos e velhas trabalhadores está de forma incontestável associada à divisão de classes e ao mundo das mercadorias, cujo consumo, usufruto e monopólio dos espaços e equipamentos são cerceados à classe empobrecida, tais como prédios,condomínios luxuosos, indústria do entretenimento e da cultura, bingos, cassinos, hotéis de luxo e, por fim, os shoppings centers enquanto catedrais das mercadorias e da pretensa nova cidade: mais limpa, mais bonita, mais segura e mais prática que a cidade real ${ }^{29}$.
Quando se trata dos espaços para as manifestações dos negócios para a realização dos megaeventos no Brasil, há um efetivo jogo sujo permeado pelos negócios abomináveis dos senhores dos anéis da FIFA e do COI, cujo ethos está pautado na acumulação de capital, entre escândalos de corrupção, compra de votos escândalos de ingressos. E tudo isso a partir de uma política olímpica não como meio de servir ao povo, mas sim para benefício próprio - e multiplique isso por mil ${ }^{30}$. Na verdade, trata-se de um comitê administrativo dos negócios da classe burguesa ${ }^{31}$.

Esse processo iníquo se dá com base no trabalho alienado, cuja essência é a não-apropriação pelo cidadão (trabalhador) dos objetos que ele mesmo produz. Quanto mais ele produz, menos se apropria desse objeto (megaeventos), quer seja do processo (construção dos edifícios esportivos), quer seja do produto (piscinas, ginásios, estádios etc.), que recai nas mãos dos capitalistas para acumulação de mais-valia e manutenção da lógica do capital ${ }^{32}$.

$\mathrm{Na}$ cidade do capita/ ${ }^{33}$, as destruições do capital engendram a

29 PADILHA, Valquíria. Shopping Center: a Catedral das Mercadorias. São Paulo: Boitempo, 2006.

30 JENNING, Andrew. Jogo Sujo. O mundo secreto da FIFA: compra de votos e escândalo de ingressos. São Paulo: Panda Books, 2011.

31 MARX, K.; ENGELS, F. Manifesto do Partido Comunista. São Paulo: Expressão Popular, 2008.

32 FERNANDES, Florestan (org.). Marx. São Paulo: Ática, 1988.

33 LEFEBVRE, Henri. A Cidade do Capital. Rio de Janeiro: DP\&A, 1999. 
manutenção da propriedade privada, a espoliação urbana e as políticas públicas de inclusão-excludente da classe trabalhadora empobrecida no contraditório imbróglio do direito à cidade, defendido por Lefebvre ${ }^{34}$. $\mathrm{O}$ direito à cidade aponta na direção de uma prática de um direito, isto é, à vida urbana, condição de um humanismo e de uma democracia renovados. O direito à cidade, no entanto, não pode prescindir da crítica ao processo de expansão capitalista nas metrópoles, cujo fetiche mercantil é a expansão imobiliária que engendra a especulação. Também não se pode esquecer que todo esse processo de construção da vida cotidiana está intimamente ligado às relações dialéticas entre campo e cidade. Isso implica abstrair que o processo de migração do campo para sociedade urbana acontece acompanhado de uma acelerada degradação, destruição e desaparecimento do campo, dos camponeses, enfim, da classe trabaIhadora rural. Assim, com todo esse processo destrutivo do trabalho no campo, as famílias são obrigadas a migrar para o mundo urbano, em cujos espaços de trabalho, lazer e moradia, sobrevivem de maneira degradante crianças, jovens, adultos e idosos.

A city marketing se constitui num campo de jogo privilegiado para os negócios dos megaeventos esportivos. Os estudos de Gilmar Mascarenhas ${ }^{35}$ apontam para a imbricação entre gestão urbana e gestão do esporte. A gestão da cidade incorpora a gestão do que esporte como uma mercadoria, como uma indústria, a exemplo do assistimos nas décadas de 70 e 80, sob a alegação da suposta falta de recursos do Estado e sob a égide da ideologia do Estado Mínimo da doutrina neoliberal. Deste modo, os gestores da cidade e do esporte vão articulando à gestão urbana, o planejamento estratégico, forjando, assim, a gestão das cidades como um dos grandes negócios do capitalismo ${ }^{36}$. Neste bojo, o esportemercadoria no limiar da guerra dos lugares (city marketing) se insurge, paulatina e contraditoriamente, de um lado, como uma forma de inclusão e ilusão de ascensão social, e, de outro lado, como prática social inacessível à classe trabalhadora ${ }^{37}$.

34 LEFEBVRE, Henri. O Direito à Cidade. São Paulo: Centauro, 2001.

35 Grupo de Pesquisa: Cidades e Práticas Espaciais: Diferentes Dinâmicas em Metrópoles Brasileiras Nacionais e Regionais/UERJ.

36 HARVEY, David. The Enigma of Capital. Oxford: University Press, 2011.

37 SILVA, Maurício R.; SILVEIRA, Juliano; BAECKER, Astrid. Políticas Públicas para o Esporte: Cidadania e Inclusão Social. In: SILVA, Murício R. (org.). Esporte, Educação, Estado e Sociedade. Chapecó,SC: Argos, 2007. 
Trata-se de uma guerra entre os lugares, forjada na crise atual do capitalismo, que está associada a um curto-circuito no ciclo de investimento no espaço construído iniciado no pós-guerra ${ }^{38}$. Enfim, os trabalhadores que constroem as cidades e os megaeventos se encontram entre o planejamento estratégico na gestão urbana, a guerra entre os lugares e as instalações esportivas construídas por eles - como um legado não para eles e sim para as elites esportivas. Isso nos mostra como o capital está muito mais fluido no planeta; e a guerra dos lugares conduz as cidades a competirem entre si para atrair mais investimentos, mesmo que a conta seja paga pelos trabalhadores ${ }^{39}$.

As políticas urbanas são orientadas para a realização de médios e megaeventos (Jogos Panamericanos, Copa do Mundo e Olimpíadas), tendo como objetivo a realização de investimentos de renovação de áreas urbanas degradas. Neste caso, são dadas prioridades, com o fim de legitimar a ação das elites e construir alianças com os interesses do complexo internacional empreendedorista. Esta lógica mercantil tem como eixo o empresariamento urbano, que, na prática, tem como finalidade, a negociação e privatização dos espaços e equipamentos públicos, em benefício do mercado imobiliário, para o exercício do culto abstrato da frugalidade e da religião da soberania do consumidor ${ }^{40}$.

Nesse jogo sujo quem paga a conta ${ }^{41}$ são os trabalhadores da construção civil e prestadores de outros serviços, que mesmo pondo a mão na massa não se reconhecem como produtores destas obras, estando, portanto, contraditoriamente, descartáveis, supérfluos e incluídos até a medula no mundo da exploração do trabalho precário, temporário e até escravo, conforme afirmou Forrester. Some-se a tudo isso a assepsia segregadora que, conforme o projeto tolerância zero $^{42}$, expulsa os trabalhadores empobrecidos ("classes perigosas") de modo violento para as periferias longínquas e precárias das grandes cidades promotoras dos megaeventos esportivos.

Não se trata de meras denúncias contra os donos do capital

38 HARVEY, David.The Enigma of Capital. Oxford: University Press, 2011.

39 MASCARENHAS, Gilmar. Megaeventos: Quem vai pagar a Conta? Jornal Brasil de Fato, disponível em: http://prod.midiaindependente.org/pt/red/2011/07/494345.shtml, em 19/07/2011.

40 MÉSZÁROS, Istvan. A Crise Estrutural do Capital. São Paulo: Boitempo, 2011.

41 MASCARENHAS, Gilmar. Megaeventos: Quem vai pagar a Conta?Jornal Brasil de Fato, disponível em: http://prod.midiaindependente.org/pt/red/2011/07/494345.shtml, em 19/07/2011.

42 WACQUANT, Loïc. As Prisões da Miséria. Paris: Raisons d'Agir, 1999. 
e amigos do esporte. Na bela cidade de Cape Town (Copa do Mundo de 2010), por exemplo, moradores das áreas degradadas foram removidos para o que se convencionou chamar de depósito de gente, ou seja, barracos de zinco de $18 \mathrm{~m}^{2}$, em locais bem longe dos turistas torcedores. Também em Johannesburgo, moradores de rua foram tirados de áreas turísticas, e imigrantes foram ameaçados em seus abrigos. E tudo isso pela imagem de um país limpo ${ }^{43}$. Este fato contrasta com o legado deixado por este megaevento. Foram construídos novos estádios e agora o governo não sabe o que fazer com eles. O caso mais dramático é o estádio Green Point, construído na Cidade do Cabo. A um custo de meio bilhão de dólares, em zona nobre da cidade (Green Point é uma bela área verde, junto ao centro e ao porto que foi renovado, tornado área de lazer), o estádio atende a um padrão de sofisticação que não era interesse do governo local.

Essa experiência segregadora da city marketing no âmbito dos megaeventos esportivos não é um privilégio da África do Sul e já foi vivenciada nos Jogos Panamericanos do Rio/2007. A partir de suas gestões mercadófilas, foi inculcada a idéia de que a cidade era potencialmente uma cidade vendável sob o rótulo de cidade olímpica, visando promovê-la mundialmente. Do mesmo modo que a cidade do Cabo, o legado do Pan-Rio desviou dinheiro público (corrupção), construiu elefantes brancos, estimulou a especulação imobiliária, não optando, assim, para com a política de moradia e, por fim, utilizou força humana barata de trabalho nas construções dos ginásios, piscinas e demais equipamentos - alguns deles hoje abandonados. ${ }^{44}$

\section{O jogo limpo dos trabalha- dores}

A problemática do mundo trabalho, especialmente na Educação Física Esportes e Lazer, não escapa às determinações do capital, sobretudo, quando se trata das relações entre capital e trabalho e suas possíveis articulações com os megaeventos esportivos.

Em relação à Copa de 2014 e a Olimpíada de 2016, há ações de expulsão dos trabalhadores empobrecidas de longas faixas ocupadas pelas populações de baixa renda, por exemplo, em Fortaleza, em nome da especulação imobiliária

43 COSTA, Paula Cesarino. Jogo Limpo. Folha de São Paulo. A2, Opinião, 31/07/2011.

44 MASCARENHAS,Gilmar. Megaeventos: Quem vai pagar a Conta? Jornal Brasil de Fato, disponível em : http://prod.midiaindependente.org/pt/red/2011/07/494345.shtml, em 19/07/2011. 
dos megaeventos, chamadas de comunidades do trilho, porque existe uma ferrovia desativada que liga o Porto. Tudo isso tem a intenção de expulsar os pobres das áreas de risco para ali implantar as áreas de ricos. Ao longo dessa via férrea, que é só de carga, tem um corredor de ocupação popular desde a década de 1950. Eles moram lá há 50,60 anos. Ocupação irregular, no jargão oficial. A cidade de Fortaleza cresceu muito ultimamente. Surgiram alguns prédios de classe média-alta junto dessa área, shopping centers, e agora eles querem varrer a ocupação de lá. São mais ou menos 30 mil pessoas que moram numa faixa de 8 km. Querem fazer o quê? Querem abrir uma avenida e essa via de circulação que vão criar é pra ligar o nada a coisa alguma. Não tem a menor razão de fazer essa via, mas vão criar para justificar a remoção e assim seguir o ciclo de valorização imobiliária. Então tem uma luta ferrenha no Ceará. Assim, se criam propostas de transporte para, quase sempre, erradicar comunidades que estão em áreas que os moradores chamam "área de rico" e não de risco, porque elas estão ali incomodando de alguma forma ${ }^{44}$.

No Rio de Janeiro, a tolerância zero já começou a todo o vapor, com desapropriações, remoções e expulsões dos moradores das áreas de risco do centro para a periferia. Em contrapartida, há um histórico de resistência implementada pelo Comitê Social do Pan, cujo grupo está hoje no Comitê Popular da Copa. Esses movimentos pretendem com suas lutas engendrar, para além da mercantilização do espaço urbano, o direito à cidade; anuncia a presença das esferas públicas democráticas de gestão das políticas públicas que ultrapassem os limites da democracia representativa liberal. Eles possibilitam a visibilização, interação, conflito e negociação entre os diferentes agentes sociais e entre esses e o poder público, em prol dos interesses públicos da classe trabalhadora ${ }^{45}$.

No Rio de Janeiro, fala-se mais sobre os jogos Olímpicos do que a Copa, porque são os Jogos que realmente vão mudar a cidade. Já estão mudando, no plano de remover 130 comunidades e dezenas de milhares de pessoas, para abrir novas vias. O problema maior é a forma como essa remoção está sendo conduzida. A Comissão de Direitos Humanos da ONU esteve na cidade, liderada por Raquel Rolnik, relatora para assuntos de 
direito à moradia. Além de não haver qualquer negociação coletiva com as comunidades, como reza a lei orgânica municipal, ficando tudo na base das pressões a cada individuo, e do uso da força policial para remover, a prefeitura simplesmente derruba as casas dos moradores que aceitaram a remoção. Já aqueles que ali permanecem, aguardando o desfecho da negociação, têm que suportar o quadro caótico, de viver entre escombros, um verdadeiro cenário de guerra. Escombros que impedem até a circulação, o ir e vir desses moradores. Escombros que abrigam lixo, ratos e comprometem a saúde pública ${ }^{46}$.

Como se pode perceber, já existem os movimentos anti-FIFA e anti-Copa, que no Cabo saíram às ruas e aqui no Brasil vão aos estádios, sob o comando da plataforma de luta da "Frente nacional dos Torcedores", visa engrossar o movimento anti-Ricardo Teixeira ${ }^{47}$. Especificamente, quando estão em pauta as tensões e conflitos entre capital e trabalho no bojo dos negócios dos megaeventos, se insurgem também as greves dos trabalhadores da construção civil, que "levantam os edifícios altos" para as competições esportivas. Esse movimento de protestos dos trabalhadores pode ser visualizado nas mídias escritas e televisadas. Trata-se do processo de construção do estádio da Fonte Nova em Salvador/BA, onde pode se escutar o eco das reivindicações: Trabalhadores da Bahia reclamam de assédio moral e ameaçam parar obras na Fonte Nova ${ }^{48}$. A greve tem como foco o problema do assédio moral sofrido pelos trabalhadores à medida que pessoas ligadas à Fonte Nova Participações (formada pelas empresas OAS e Odebrecht) estariam fazendo ameaças para que $o$ cronograma das obras seguisse no prazo estabelecido. Esses trabalhadores reivindicam, entre outras coisas, a contratação de um plano de saúde para os trabalhadores, além do aumento no valor pago pela participação nos lucros e nas horasextras realizadas. Também reivindicam não mais executar funções para além da capacidade física, com o fim único em avançar loucamente o programa, acelerando o ritmo das obras. Quando alguém se nega,eles ameaçam demiti-los ${ }^{49}$.

As greves e paralisações dos trabalhadores da construção civil no âmbito dos megaeventos esportivos tiveram seu apogeu nas

46 MASCARENHAS, Gilmar. Megaeventos: Quem vai pagar a Conta?Jornal Brasil de Fato, disponível em: http://prod.midiaindependente.org/pt/red/2011/07/494345.shtml, em 19/07/2011.

47 COSTA, Paula Cesarino. Jogo Limpo. Folha de São Paulo. Opinião, A2, 31/07/2011.

48 CALIPO, Thales. Folha de São Paulo, 19/08/2011.

49 Ibid. 
obras do Rio de Janeiro (Maracanã) e Minas Gerais (Mineirão). No Rio de Janeiro, não se tratou de um fato isolado no que se refere aos preparativos para a Copa do Mundo de 2014. As melhorias prometidas pelo Consórcio Maracanã 2014 não foram suficientes. Os trabalhadores reivindicaram uma proposta para além de $10 \%$ no aumento da cesta básica, apresentado pelo patronato. “Eles pedem também a extensão do plano de saúde para os familiares e a equiparação dos pisos salariais de algumas categorias com o que é praticado no mercado", afirmou o presidente do Sindicato dos Trabalhadores nas Indústrias da Construção Pesada (Sintraicp) ${ }^{51}$. Nesta mesma perspectiva, os trabalhadores em obras da Copa do Mundo de 2014 no Mineirão fizeram paralisação pela segunda vez. Assim como no Maracanã, o Sindicato dos Trabalhadores da Construção de Belo Horizonte salienta a necessidade da greve para pedir reajuste salarial, cesta básica, plano de saúde e assistência às famílias dos operários. Essas reivindicações são oriundas da organização dos trabalhadores da construção civil em outras obras, diante das condições precárias de trabalho. Um exemplo disso é que até a falta de bife no prato já provocou rebelião em canteiros de obras no país, além de quartos apertados e falta d'água ${ }^{52}$. A greve dos trabalhadores da construção civil dos megaeventos esportivos faz rima com a greve dos trabalhadores da Educação (professores), realizada em 17 estados brasileiros no ano de $2011^{53}$, cuja centralidade é a luta pelo piso salarial e contra a mercantilização da educação. Trata-se da luta para uma educação para além do capital, uma luta contra a exploração, a opressão, a dominação e a alienação, ou seja, contra o domínio do capital, cuja tarefa educacional é a transformação social ampla emancipadora ${ }^{54}$.

$* * * * * *$

Antes de concluir, destacamos a homenagem especial que essa edição faz ao professor Lino Castelani Filho, recentemente aposentado pela FEF/UNICAMP. Amigo da Motrivivência de longa data, Lino teve publicado um texto seu na edição número 1 da revista (ver seção Imagens e Homenagem).

50 Conforme: http://www.uol.com.br

51 lbid.

52 Cf. dados da CNTE - Confederação Nacional dos Trabalhadores em Educação. Ver em: http:// www.cnte.org.br/index.php/quadro-de-greve

53 SADER, Emir. Prefácio. In: A Educação para além do Capital. São Paulo: Boitempo, 2005. 
Ano XXIII, n 36 , junho/2011

Para encerrar este editorial só nos resta continuar com a música de Zé Geraldo, iniciada na epígrafe do início deste editorial:

Esta dor doeu mais forte

Porque eu deixei o norte

Eu me pus a me dizer Lá a seca castigava, mas o pouco que eu plantava

Tinha direito a comer Tá vendo aquela igreja moço?

Onde o padre diz amém

Pus o sino e o badalo

Enchi minha mão de calo

Lá eu trabalhei também

Lá sim valeu a pena

Tem quermesse, tem novena

E o padre me deixa entrar

Foi lá que Cristo me disse

Rapaz deixe de tolice

Não se deixe amedrontar

Fui eu quem criou a terra

Enchi o rio fiz a serra

Não deixei nada faltar

Hoje o homem criou asas

E na maioria das casas

Eu também não posso entrar

Florianópolis, outubro de 2011.

$$
\begin{array}{r}
\text { Mauricio Roberto da Silva } \\
\text { Giovani De Lorenzi Pires } \\
\text { (editores) }
\end{array}
$$

Marcelo de Paula Melo

(editor associado deste número) 